\title{
Following the Amphibolite to Greenschist Metamorphic Path through the Structural Parameters of Spinels from Amsaga (Mauritania)
}

\author{
Davide Lenaz $^{1, * \mathbb{C}}$, Henrik Skogby ${ }^{2}$, Nicola Rigonat ${ }^{1,3}$ and Julien Berger ${ }^{4,5}$ \\ 1 Dipartimento di Matematica e Geoscienze, University of Trieste, Via Weiss 8, I-34128 Trieste, Italy \\ 2 Department of Geosciences, Swedish Museum of Natural History, Box 50007, SE-10405 Stockholm, Sweden; \\ henrik.skogby@nrm.se \\ 3 Dipartimento di Scienze Chimiche e Geologiche, Università di Cagliari, Via Trentino 51, 09127 Cagliari, Italy; \\ nicola.rigonat@unica.it \\ 4 Géosciences Environnement Toulouse (GET), Observatoire de Midi-Pyrénées, Université de Toulouse, CNRS, \\ IRD, 14 avenue Edouard Belin, F-31400 Toulouse, France; julien.berger@get.omp.eu \\ 5 Geological Institute, ETH Zürich, 8092 Zürich, Switzerland \\ * Correspondence: lenaz@units.it; Tel.: +39-040-5582209
}

Received: 24 November 2017; Accepted: 15 January 2018; Published: 18 January 2018

\begin{abstract}
We investigated the crystal and structural behavior of several Cr-bearing spinels from the Archean chromitites of Amsaga (Mauritania). The chemical and structural data testified a retrograde metamorphism from amphibolite to greenschist facies, witnessed by relative changes in the amount of all the major oxides $\left(\mathrm{Cr}, \mathrm{Al}, \mathrm{Mg}, \mathrm{Fe}^{2+}, \mathrm{Fe}^{3+}\right)$, the relative proportion of $\mathrm{Fe}^{3+} / \mathrm{Fe}_{\text {tot }}$ as well as the structural parameters, including the cell edge and the oxygen coordinate. The general agreement between electron microprobe and Mössbauer data indicates that the analyzed spinels are stoichiometric. The structural data revealed that the oxygen positional parameter of amphibole-bearing samples is the highest observed among Cr-bearing spinels with similar Cr\# and

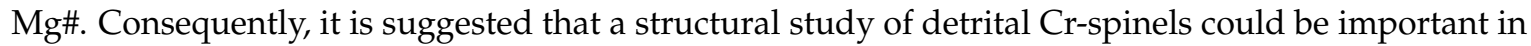
discriminating an amphibole-chromitite source from an ophiolite source.
\end{abstract}

Keywords: Cr-bearing spinel; chemistry; X-ray single crystal diffraction; Mössbauer spectroscopy; Archean; Mauritania

\section{Introduction}

Chromium-bearing spinels are commonly considered important petrogenetic indicators [1-5]—due to general relationships between spinel chemistry, rock type, and post-crystallization processes-which can be understood from different types of analysis of spinel-bearing assemblages [4,6,7].

The relationships between chemistry, structural parameters, and genetic behaviors have been considered by several authors. In particular, the crystal chemistry of Cr-spinels from different lithologies, including mantle xenoliths [8-13], ophiolites [14-18], Alpine peridotites [19,20], komatiites [21], layered complexes [22-24], inclusions in diamonds and kimberlites [25] as well as in meteorites [26,27], have previously been studied to better understand genesis and/or oxidation mechanisms.

The massive chromitites samples analyzed in this work come from the Archaean Guelb el Azib layered complex (GAC; Amsaga Area, West African craton, Mauritania; Figure 1), a meta-igneous body, comparable to Archeaen anorthosite complexes [28]. In order to better constrain the genesis and the metamorphic path of these chromitites, the crystal chemical parameters of single crystals of Cr-spinels have been studied. As some authors [14,15,17,18,29-34] observed non-stoichiometry of spinels from serpentinized ophiolites and of spinels altered in sedimentary environments, the 
$\mathrm{Fe}^{3+} / \mathrm{Fe}_{\text {tot }}$ ratio has also been determined by Mössbauer spectroscopy. This is particularly important because the estimation of $f_{\mathrm{O} 2}$ via geothermobarometry is dependent on the quantification of the $\mathrm{Fe}^{3+}$ contents, which play a fundamental role in the calculation of both magnetite activity in Cr-spinel and equilibrium temperatures. If deviations from stoichiometry occur and are not detected, the resulting errors may be very large. By combining these data with those derived from structural refinement and electron microprobe analysis (EMPA), it will be possible to establish if the studied crystals of chromite are stoichiometric or not.
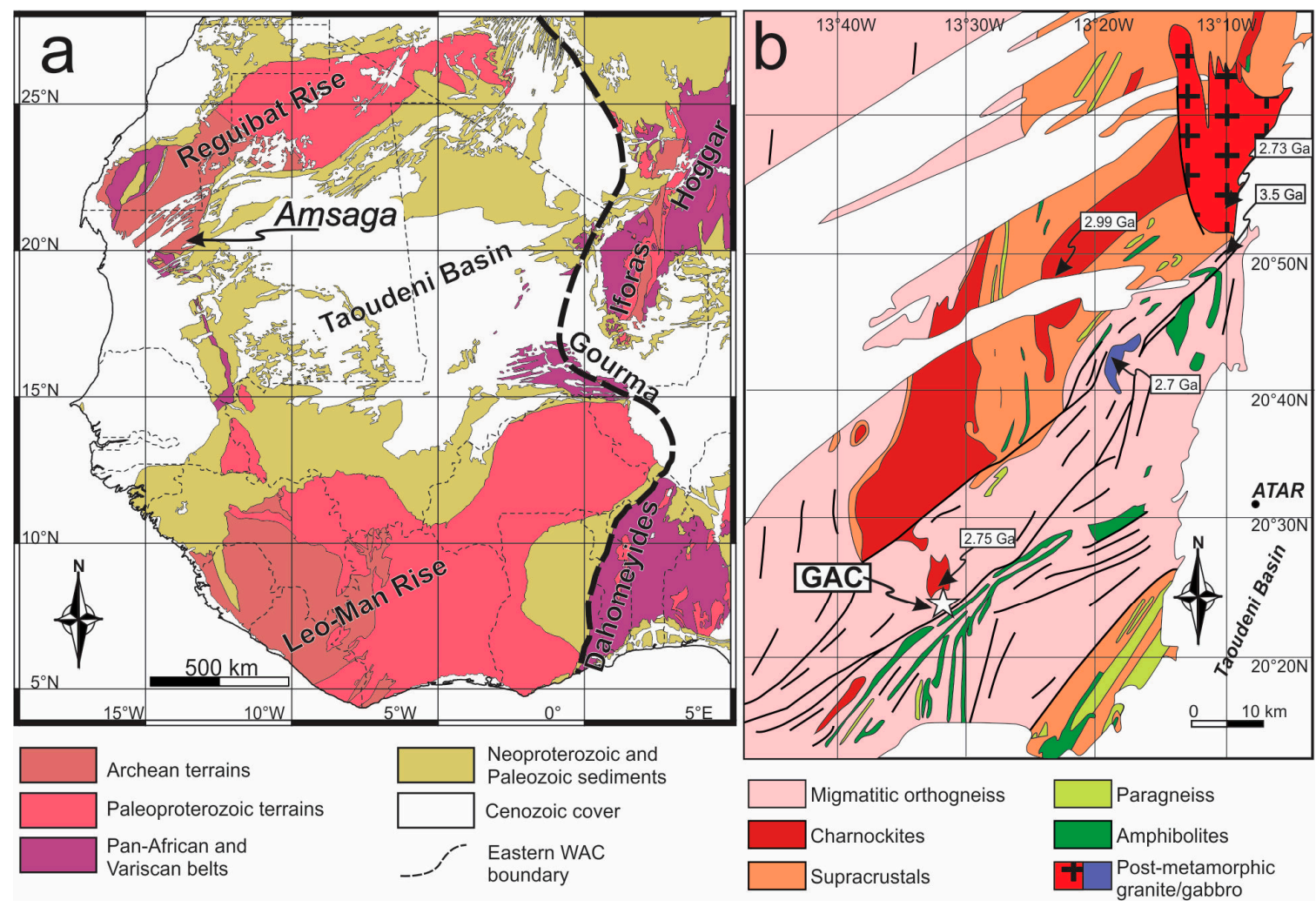

Figure 1. Geological maps of the West African Craton (a) and the Amsaga area (b). The map of Amsaga and the geochronological information are from Potrel (1996) [35]. GAC: Guelb el Aziz Complex.

Hence, the aim of this work, is to verify (a) if it is possible to follow the metamorphic path from the amphibolite to the greenschist facies through structural analyses of Cr-spinels; (b) if it is possible to discriminate the spinels from amphibolites from those with analogous chemistry of ophiolitic and layered complex occurrences, based on structural data; and (c) if the metamorphic overprint produced any non-stoichiometry in the studied Cr-spinels.

\section{Materials and Methods}

The Amsaga area, located in the Southern part of the Reguibat Shield, belongs to the Archaean domain of the West African craton. This zone is composed of supracrustal units, mainly BIFs (Banded Iron Formations), impure marbles, amphibolites and metapelites, with granite-gneiss terrains, dominated by migmatitic orthogneiss of TTG (tonalite-trondhjemite-granodiorite) affinity. Potrel (1996) [35] dated the migmatized orthogneiss at 3.5 Ga, while charnockitic plutons intruded the supracrustal sequences between 2.9-3.0 Ga [36-38]. A main tectono-thermal event affected most of the units from Amsaga between 2.9 and $2.7 \mathrm{Ga}$ [36,37], the younger age representing the emplacement of a non-metamorphosed mafic intrusion.

Chromitites are found in dissected complexes formed by the association of serpentinites (former olivine-rich cumulates), mafic olivine-amphibole-spinel-plagioclase rocks (meta-troctolites), 
amphibolites and recrystallized anorthosites [39]. The whole complex is in tectonic contact with TTG orthogneiss and supracrustal BIF, cipolin and amphibolites. It has been affected by high temperature metamorphism and deformation, up to $900{ }^{\circ} \mathrm{C}$, at $5 \mathrm{kbar}$, with retrogression, to various extents, under amphibolite and greenschist-grade conditions. Most chromitites form meter-scale lenses in the ultramafic, olivine-bearing units but some lenses have also be found in close association with leuco-amphibolites and anorthosites. These characteristics allow us to link this complex to well-known, worldwide Archaean anorthosite complexes [28], such as Fiskenaesset in Greenland [40] and Sittampundi in India [41,42].

On the basis of their dominant silicate matrix minerals, the massive chromitites (from 50 to 90 vol \% chromite) investigated in this study can be subdivided into amphibole-chromitite (AMP-CHR, hereafter), chlorite-chromitite (CHL-CHR) and talc-serpentine-chromitite (TS-CHR). The amphibole-chromitites show rounded chromite grains (up to $0.5 \mathrm{~cm}$ width), surrounded by high-Al Mg-hornblende, with no signs of retrogression under greenschist-grade conditions (Figure 2a). Chlorite- and talc-serpentine chromitite show angular spinel grains (up to several centimeters width) and are affected to various extents by greenschist hydrothermal metamorphism. The chromite grains can indeed show spongy textures with numerous chlorite inclusions (Figure $2 b$ ) and a ferritchromit replacement.

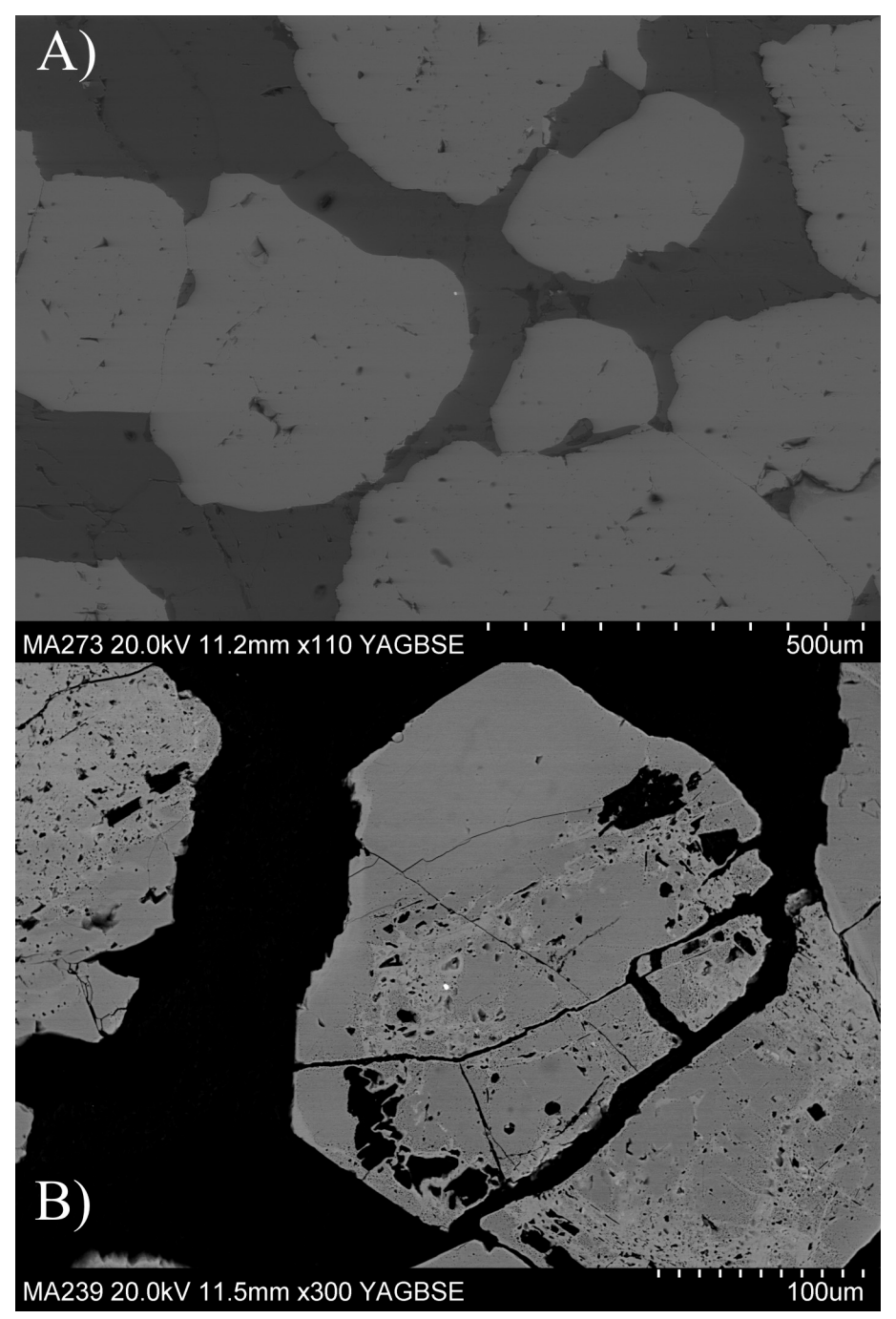

Figure 2. Electron backscattered images of textural relationships in Cr-bearing spinels from amphibole-chromitite (A) and chlorite-chromitite (B). 


\subsection{X-ray Single Crystal Diffraction}

Nine single crystals of Cr-spinel were analyzed by X-ray diffraction. Data were recorded on an automated KUMA-KM4 (K-geometry) diffractometer (KUMA, Wroclaw, Poland), using MoK $\alpha$ radiation, monochromatized by a flat graphite crystal. Twenty-four equivalents of the 1284 , at approximately $80^{\circ}$ were accurately centered at both sides of $2 \theta$, and the MoK $\alpha 1$ peak barycenter was used for cell parameter determination. Data collection was made, according to [43], up to $55^{\circ}$ of $\theta$ in the $\omega-2 \theta$ scan mode, at a scan width of $1.8^{\circ} 2 \theta$, and a counting time from 20 to $50 \mathrm{~s}$, depending on the peak standard uncertainty. Structural refinement, using the SHELX-97 program [44], was carried out against $\mathrm{Fo}^{2}{ }_{h k l}$ in the $F d-3 m$ space group (with origin at $-3 m$ ), since no evidence of different symmetry appeared. Scattering factors were taken from [45,46]. Neutral scattering curves-Mg vs. Fe in T site and Cr vs. Al in M site-were assigned, with the constraints of full site occupancy and equal displacement parameters. Oxygen ionization was varied from one grain to another, in order to reach the best fit between structural refinement and chemical analyses and to obtain the best value for all conventional agreement factors.

It should be noted that the analyzed crystals are full of inclusions, and this fact could have caused a depletion in some structural parameters. Crystallographic data are listed in Table 1.

Table 1. Results of structure refinement.

\begin{tabular}{|c|c|c|c|c|c|c|c|c|c|}
\hline Sample & MA422 & MA238 & MA44 & MA400 & MA17 & MA226 & MA440 & MA425 & MA273 \\
\hline Matrix & Talc-Serp & Chl & Chl & Chl & Chl & Chl & Amph & Amph & Amph \\
\hline $\mathrm{a}_{0}$ & $8.3571(5)$ & $8.2933(3)$ & $8.2854(5)$ & $8.3142(4)$ & $8.2770(4)$ & $8.2825(2)$ & $8.2561(7)$ & $8.2635(6)$ & $8.2601(4)$ \\
\hline $\mathrm{u}$ & $0.2626(2)$ & $0.2634(2)$ & $0.2630(1)$ & $0.2628(2)$ & $0.2633(1)$ & $0.2628(1)$ & $0.2635(1)$ & $0.2638(2)$ & $0.2633(1)$ \\
\hline $\mathrm{T}-\mathrm{O}$ & $1.9920(5)$ & $1.9892(3)$ & $1.9800(6)$ & $1.9847(4)$ & $1.9828(4)$ & $1.9764(2)$ & $1.9809(7)$ & $1.9865(7)$ & $1.9788(3)$ \\
\hline $\mathrm{M}-\mathrm{O}$ & $1.990(1)$ & $1.968(1)$ & $1.970(1)$ & $1.9575(9)$ & $1.965(1)$ & $1.9705(8)$ & $1.9575(9)$ & $1.959(2)$ & $1.961(1)$ \\
\hline m.a.n. T & $24.3(8)$ & $24.5(4)$ & $21.6(4)$ & $20.9(4)$ & $21.4(3)$ & $19.9(2)$ & $22.4(5)$ & $23.8(6)$ & $20.5(4)$ \\
\hline m.a.n. M & $22.7(9)$ & $19.8(2)$ & $20.5(5)$ & $21.5(3)$ & $19.5(3)$ & $20.1(2)$ & $18.8(4)$ & $18.8(3)$ & $19.2(4)$ \\
\hline $\mathrm{U}(\mathrm{M})$ & $0.0054(2)$ & $0.0057(1)$ & $0.0048(2)$ & $0.0050(2)$ & $0.0060(1)$ & $0.0064(1)$ & $0.0061(2)$ & $0.0048(3)$ & $0.0054(2)$ \\
\hline $\mathrm{U}(\mathrm{T})$ & $0.0076(3)$ & $0.0078(2)$ & $0.0076(2)$ & $0.0078(4)$ & $0.0087(2)$ & $0.0085(2)$ & $0.0081(2)$ & $0.0089(4)$ & $0.0078(2)$ \\
\hline $\mathrm{U}(\mathrm{O})$ & $0.0072(5)$ & $0.0083(4)$ & $0.0070(4)$ & 0.0071 (5) & $0.0084(4)$ & $0.0087(2)$ & $0.0084(4)$ & $0.0085(7)$ & $0.0075(4)$ \\
\hline $\mathrm{N}_{\text {refl }}$ & 133 & 132 & 137 & 118 & 129 & 166 & 134 & 87 & 137 \\
\hline R1 & 3.26 & 2.75 & 2.90 & 3.25 & 2.91 & 3.38 & 2.89 & 3.40 & 3.29 \\
\hline$w R 2$ & 6.45 & 5.41 & 5.07 & 5.51 & 5.10 & 6.05 & 5.61 & 5.13 & 5.41 \\
\hline GooF & 1.235 & 1.254 & 1.326 & 1.279 & 1.300 & 1.403 & 1.209 & 1.241 & 1.248 \\
\hline
\end{tabular}

Note: $\mathrm{a}_{0}$ : cell parameter $(\AA)$; $\mathrm{u}$ : oxygen positional parameter; $\mathrm{T}-\mathrm{O}$ and $\mathrm{M}-\mathrm{O}$ : tetrahedral and octahedral bond lengths $(\AA)$, respectively; m.a.n. $\mathrm{T}$ and $\mathrm{M}$ : mean atomic number; $\mathrm{U}(\mathrm{M}), \mathrm{U}(\mathrm{T}), \mathrm{U}(\mathrm{O})$ : displacement parameters for $\mathrm{M}$ site, T site and O; $\mathrm{N}_{\text {Refl }}$ : number of unique reflections; R1 all (\%), wR2 (\%), GooF as defined in Sheldrick (2008) [44]; Space Group: $F d-3 m$. Origin fixed at $-3 m, \mathrm{Z}=8$; reciprocal space range: $-19<\mathrm{h}<19 ; 0<\mathrm{k}<19 ; 0<1<19$. Serp: serpentine; Chl: chlorite; Amph: amphibole.

\subsection{Electron Microprobe Analyses}

After X-ray data collection, the same crystals used for X-ray data collection were mounted on glass slides, polished and carbon coated for electron microprobe analyses on a CAMECA-CAMEBAX microprobe (CAMECA, Gennevilliers Cedex, France) at IGG-CNR (Istituto di Geoscienze e Georisorse-Consiglio Nazionale delle Ricerche), Padua, operating at $15 \mathrm{kV}$ and $15 \mathrm{nA}$. A 20 s counting time was used for both the peak and total background. Synthetic $\mathrm{MgCr}_{2} \mathrm{O}_{4}$ and $\mathrm{FeCr}_{2} \mathrm{O}_{4}$ spinels were used for $\mathrm{Mg}$, $\mathrm{Cr}$ and Fe determination, $\mathrm{Al}_{2} \mathrm{O}_{3}$ for $\mathrm{Al}, \mathrm{MnTiO}_{3}$ for $\mathrm{Ti}$, and $\mathrm{Mn}, \mathrm{NiO}$ for $\mathrm{Ni}$ and sphalerite for Zn. The following diffracting crystals were used: TAP for Al and Mg, PET for Ti and Ti, and LIF for $\mathrm{Cr}, \mathrm{Fe}, \mathrm{Mn}, \mathrm{Ni}, \mathrm{V}$ and $\mathrm{Zn}$. Raw data were reduced by a PAP-type correction software provided by CAMECA. Chemical data are listed in Table 2. 
Table 2. Mean chemical analyses (10-15 spot analyses for each crystal) and cation distribution in $\mathrm{T}$ and $\mathrm{M}$ sites of the analysed $\mathrm{Cr}$-spinels, on the basis of four oxygen atoms per formula unit.

\begin{tabular}{|c|c|c|c|c|c|c|c|c|c|}
\hline Sample & MA422 & MA238 & MA44 & MA400 & MA17 & MA226 & MA440 & MA425 & MA273 \\
\hline Matrix & Talc-Serp & Chl & Chl & Chl & Chl & Chl & Amph & Amph & Amph \\
\hline $\mathrm{MgO}$ & $1.9(2)$ & $2.3(1)$ & $7.2(1)$ & $7.7(2)$ & $6.4(1)$ & $9.6(5)$ & $5.3(2)$ & $4.5(1)$ & $8.8(1)$ \\
\hline $\mathrm{TiO}_{2}$ & $0.33(8)$ & 0.0 & $0.28(4)$ & $0.33(4)$ & $0.32(5)$ & $0.30(6)$ & $0.24(1)$ & $0.26(9)$ & 0.33 (5) \\
\hline $\mathrm{V}_{2} \mathrm{O}_{3}$ & $0.21(3)$ & $0.23(3)$ & $0.15(3)$ & $0.14(4)$ & $0.21(3)$ & $0.17(3)$ & $0.22(2)$ & $0.21(6)$ & $0.24(3)$ \\
\hline $\mathrm{Cr}_{2} \mathrm{O}_{3}$ & 46.0 (4) & $37.8(3)$ & $42.0(3)$ & $49.7(4)$ & $37.9(4)$ & 44.9 (3) & $37.2(6)$ & $37.4(5)$ & $39.4(4)$ \\
\hline $\mathrm{MnO}$ & $1.2(1)$ & $0.82(7)$ & $0.36(3)$ & $0.35(3)$ & $0.43(4)$ & $0.40(8)$ & $0.36(3)$ & $0.34(3)$ & $0.32(3)$ \\
\hline $\mathrm{ZnO}$ & $0.37(4)$ & $0.64(5)$ & $0.45(4)$ & $0.31(4)$ & $0.31(5)$ & $0.17(8)$ & $0.27(5)$ & $0.28(8)$ & $0.28(8)$ \\
\hline Sum & 98.41 & 99.56 & 99.14 & 98.11 & 99.65 & 99.54 & 100.37 & 100.3 & 100.6 \\
\hline $\mathrm{FeO}$ & $28.6(5)$ & $30.2(4)$ & $23.1(5)$ & $21.3(5)$ & $25.3(4)$ & $19.9(6)$ & $27.7(5)$ & $28.8(3)$ & $22.5(2)$ \\
\hline $\mathrm{Fe}_{2} \mathrm{O}_{3}$ & 14.7 & 8.2 & 8.9 & 7.0 & 7.0 & 5.4 & 3.9 & 3.5 & 4.9 \\
\hline Sum & 99.88 & 100.4 & 100.03 & 98.80 & 100.35 & 100.08 & 100.70 & 100.76 & 101.00 \\
\hline \multicolumn{10}{|l|}{ T Site } \\
\hline $\mathrm{Fe}^{3+}$ & $0.037(5)$ & $0.056(4)$ & $0.039(4)$ & $0.042(5)$ & $0.005(1)$ & $0.068(12)$ & $0.034(7)$ & $0.061(7)$ & $0.020(3)$ \\
\hline $\mathrm{Mn}$ & $0.036(2)$ & $0.023(2)$ & $0.010(1)$ & $0.010(1)$ & $0.012(1)$ & $0.011(2)$ & 0.009 (1) & 0.009 (1) & $0.008(1)$ \\
\hline $\mathrm{Zn}$ & $0.009(1)$ & $0.016(1)$ & $0.011(1)$ & $0.008(1)$ & $0.007(1)$ & $0.004(2)$ & $0.006(1)$ & $0.007(2)$ & $0.002(1)$ \\
\hline \multicolumn{10}{|l|}{ M Site } \\
\hline $\mathrm{Al}$ & $0.281(23)$ & $0.788(7)$ & $0.653(7)$ & $0.474(7)$ & $0.807(6)$ & $0.716(8)$ & $0.920(12)$ & $0.947(8)$ & $0.856(7)$ \\
\hline $\mathrm{Cr}$ & $1.298(16)$ & $1.000(8)$ & $1.090(8)$ & $1.327(10)$ & $0.963(9)$ & $1.128(12)$ & $0.936(12)$ & $0.946(8)$ & $0.972(8)$ \\
\hline $\mathrm{Mg}$ & $0.048(6)$ & $0.011(2)$ & $0.064(3)$ & $0.029(2)$ & $0.045(2)$ & $0.025(4)$ & $0.034(3)$ & $0.032(2)$ & $0.056(2)$ \\
\hline $\mathrm{Fe}^{2+}$ & $0.010(2)$ & $0.043(2)$ & $0.000(0)$ & $0.020(2)$ & $0.005(1)$ & $0.050(4)$ & $0.035(3)$ & $0.037(2)$ & $0.003(1)$ \\
\hline $\mathrm{Fe}^{3+}$ & $0.345(15)$ & $0.150(6)$ & $0.177(8)$ & $0.134(9)$ & $0.165(7)$ & 0.065 (11) & $0.056(9)$ & $0.024(4)$ & $0.096(6)$ \\
\hline $\mathrm{Ni}$ & $0.002(1)$ & $0.003(1)$ & $0.003(1)$ & $0.003(1)$ & $0.002(1)$ & $0.003(1)$ & $0.002(1)$ & $0.003(1)$ & $0.004(1)$ \\
\hline $\mathrm{Ti}$ & $0.008(2)$ & & $0.007(1)$ & $0.008(1)$ & $0.008(1)$ & $0.008(1)$ & $0.006(2)$ & $0.006(2)$ & $0.008(1)$ \\
\hline $\mathrm{V}$ & $0.006(1)$ & $0.006(1)$ & $0.004(1)$ & $0.004(1)$ & $0.005(1)$ & $0.004(1)$ & $0.005(1)$ & $0.006(2)$ & $0.007(1)$ \\
\hline
\end{tabular}

Note: $\mathrm{Fe}^{3+}$ from stoichiometry. $\mathrm{F}(\mathrm{x})$ : minimisation factor, which takes into account the mean of square differences between calculated and observed parameters, divided by their standard deviations. Serp: serpentine; Chl: chlorite; Amph: amphibole; $\mathrm{Cr} \#: \mathrm{Cr} /(\mathrm{Cr}+\mathrm{Al}) ; \mathrm{Mg} \# \mathrm{Mg} /\left(\mathrm{Mg}+\mathrm{Fe}^{2+}\right) ; \mathrm{Fe}^{3+} \#: \mathrm{Fe}^{3+} /\left(\mathrm{Fe}^{3+}+\mathrm{Cr}+\mathrm{Al}\right)$ Estimated standard deviations are in brackets.

\subsection{Cation Distribution}

Several different procedures may be adopted to determine cation distribution $[47,48]$, and satisfying results can generally be obtained by combining data from single-crystal X-ray structural refinements and electron microprobe analyses. This approach simultaneously takes into account both the structural and chemical data and reproduces the observed parameters by optimizing cation distributions. Differences between measured and calculated parameters are minimized by a function, $\mathrm{F}(\mathrm{x})$, taking into consideration different observed quantities, such as $\mathrm{a}_{0}, u$, $\mathrm{T}-$ and M-m.a.n., atomic proportions, and constraints imposed by the crystal chemistry (total charges and $\mathrm{T}$ and $\mathrm{M}$ site populations). Several minimization cycles of $\mathrm{F}(\mathrm{x})$ were performed up to convergence. A summary of the procedure can be found in [27]. The obtained cation distributions are listed in Table 2.

\subsection{Mössbauer Spectroscopy}

The oxidation state of Fe in the studied samples was determined by Mössbauer spectroscopy, using a conventional spectrometer system (WissEl GmbH, Starnberg, Germany), operated in constant acceleration mode, with a triangular reference signal and a ${ }^{57} \mathrm{Co}$, Rh matrix source with a nominal activity of $50 \mathrm{mCi}$. Absorbers were prepared by grinding $8-20 \mathrm{mg}$ of sample material with ca $80 \mathrm{mg}$ acrylic resin (Transoptic powder), followed by pressing to discs of 12-mm diameter, under moderate heating. The Fe thickness of the absorbers were kept below that required for the thin-absorber approximation $\left(<5 \mathrm{mg} \mathrm{Fe} / \mathrm{cm}^{2}\right)$. Spectra were acquired over 1024 channels in the velocity range -4.5 to $+4.5 \mathrm{~mm} / \mathrm{s}$, and calibrated against an $\alpha$-Fe foil (thickness $=25 \mu \mathrm{m}$ ) before folding and reduction to 256 
channels. Data collection time varied from two to five days. A least-squares fitting software (MDA) [49] was used to analyze the spectra. Most spectra could be adequately fitted with one doublet assigned to $\mathrm{Fe}^{3+}$ and three doublets assigned to $\mathrm{Fe}^{2+}$; however, one sample (MA422) displayed additional absorption bands caused by a magnetic phase. A spectrum acquired in a wider velocity range $(-11$ to $+11 \mathrm{~mm} / \mathrm{s}$ ) showed that this phase was magnetite (also observed in the serpentinite-bearing matrix). Several studies have shown that the recoil-free fractions for $\mathrm{Fe}^{2+}$ and $\mathrm{Fe}^{3+}$ are unequal $[50,51]$. The absorption area ratios obtained for the $\mathrm{Fe}^{2+}$ and $\mathrm{Fe}^{3+}$ doublets were accordingly corrected for unequal recoil-free fractions based on the data presented in [50] and the composition of the studied samples, using a value of 0.687 for $\mathrm{Fe}^{2+}$ and 0.887 for $\mathrm{Fe}^{3+}$. Results are listed in Table 3 .

Table 3. Mössbauer parameters obtained for spinel samples at room temperature.

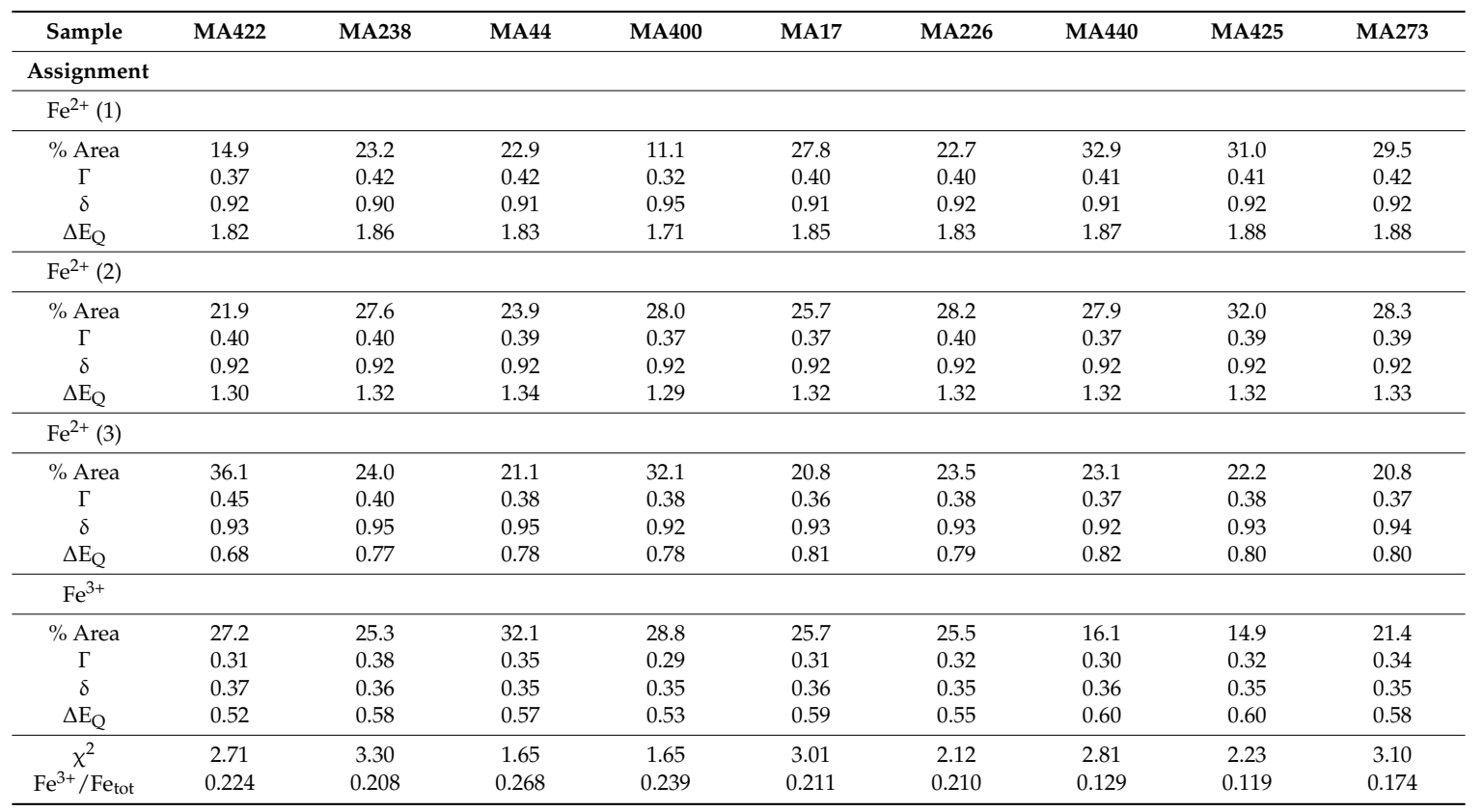

Note: $\%$ Area $=$ integrated intensities given in $\%$ of total $\mathrm{Cr}$-spinel absorption area; $\Gamma=$ full width at half maximum in $\mathrm{mm} / \mathrm{s} ; \delta=$ centroid shift in $\mathrm{mm} / \mathrm{s} ; \Delta \mathrm{E}_{\mathrm{Q}}=$ quadrupole splitting in $\mathrm{mm} / \mathrm{s}$. For sample MA422, the absorption area of a magnetic phase $\left(32.1 \%\right.$ ) was excluded from the listed integrated intensities. The $\mathrm{Fe}^{3+} / \mathrm{Fe}_{\text {tot }}$ ratios were calculated from the observed integrated intensity relations using recoil-free fractions of $0.687 \mathrm{for} \mathrm{Fe}^{2+}$ and 0.887 for $\mathrm{Fe}^{3+}$. Errors in $\mathrm{Fe}^{3+} / \mathrm{Fe}_{\text {tot }}$ ratios are estimated to be \pm 0.02 . The obtained $\Gamma$-values for the Fe-standard were within $0.15-0.16 \mathrm{~mm} / \mathrm{s}$.

\section{Results}

Regarding the structural data, the cell edge of the analyzed crystals ranges between 8.2561 (7) and 8.3571 (5) $\AA$, while the oxygen positional parameter is between 0.2626 (2) and 0.2638 (2) (Table 1). It is possible to discriminate the samples into three groups, according to their host lithology and their structural parameters. The sample occurring in TS is characterized by a larger cell edge $(8.3571 \AA)$ and lower $u$ value $(0.2626)$, whereas those occurring in AMP show the smallest cell edges (8.2561-8.2635 $\AA$ ) and the highest $u$ values (0.2633-0.2638), and those from CHL show values in between the other two groups (8.2770-8.3142 ^; 0.2628-0.2634, respectively). In Figure 3, for comparison, samples from layered complexes, such as Bushveld, Rum and Stillwater complexes [22-24], ophiolites [14,16-18], komatiites [21] and synthetic $\mathrm{MgCr}_{2} \mathrm{O}_{4}-\mathrm{FeCr}_{2} \mathrm{O}_{4}$ series [52], are plotted. While there is a certain overlap for the Cr-spinels in chlorite matrix, the other spinels fall outside the previously defined fields.

Also, the chemical compositions of the studied samples show distinct variations, according to the host lithologies (TS-CHR, CHL-CHR and AMP-CHR). These three groups have different chemical characteristics, especially regarding the $\mathrm{Cr}, \mathrm{Fe}^{3+}$ and $\mathrm{Al}$ contents (Table 2); in detail, $\mathrm{Cr}_{2} \mathrm{O}_{3}$ spans from 46 wt \% (TS-CHR) to 37-50 wt \% (CHL-CHR) and 37-39 wt \% (AMP-CHR), $\mathrm{Fe}_{2} \mathrm{O}_{3}$ from 14.7 wt \% 
(TS-CHR) to 5.4-8.9 wt \% (CHL-CHR) and 3.5-4.9 wt \% (AMP-CHR). The $\mathrm{Al}_{2} \mathrm{O}_{3}$ content varies strongly from $6.5 \mathrm{wt} \%$ (TS-CHR) to 12-22 wt \% (CHL-CHR) and 24-25 wt \% (AMP-CHR), whereas MgO is very low in the TS-CHR spinel (about $2 \mathrm{wt} \%$ ), within 2-10 wt \% in the CHL-CHR samples, and spans from 5 to $9 \mathrm{wt} \%$ in the AMP-CHR samples. Other oxides are rather low, with $\mathrm{TiO}_{2}$ showing an average value of about $0.3 \mathrm{wt} \%$. In the frequently used $\mathrm{Cr}-\mathrm{Fe}^{3+}-\mathrm{Al}$ ternary plot (Figure 4 ), the studied samples plot in an area where samples from ophiolites, komatiites and continental layered intrusions partly overlap, while in the Cr\# vs. Fe\# diagram (Figure 5), where $\mathrm{Cr} \#$ is $\mathrm{Cr} /(\mathrm{Cr}+\mathrm{Al})$ and $\mathrm{Fe} \#$ is $\mathrm{Fe}^{2+} /\left(\mathrm{Fe}^{2+}+\mathrm{Mg}\right)$, they fall outside the fields covered by these lithologies.

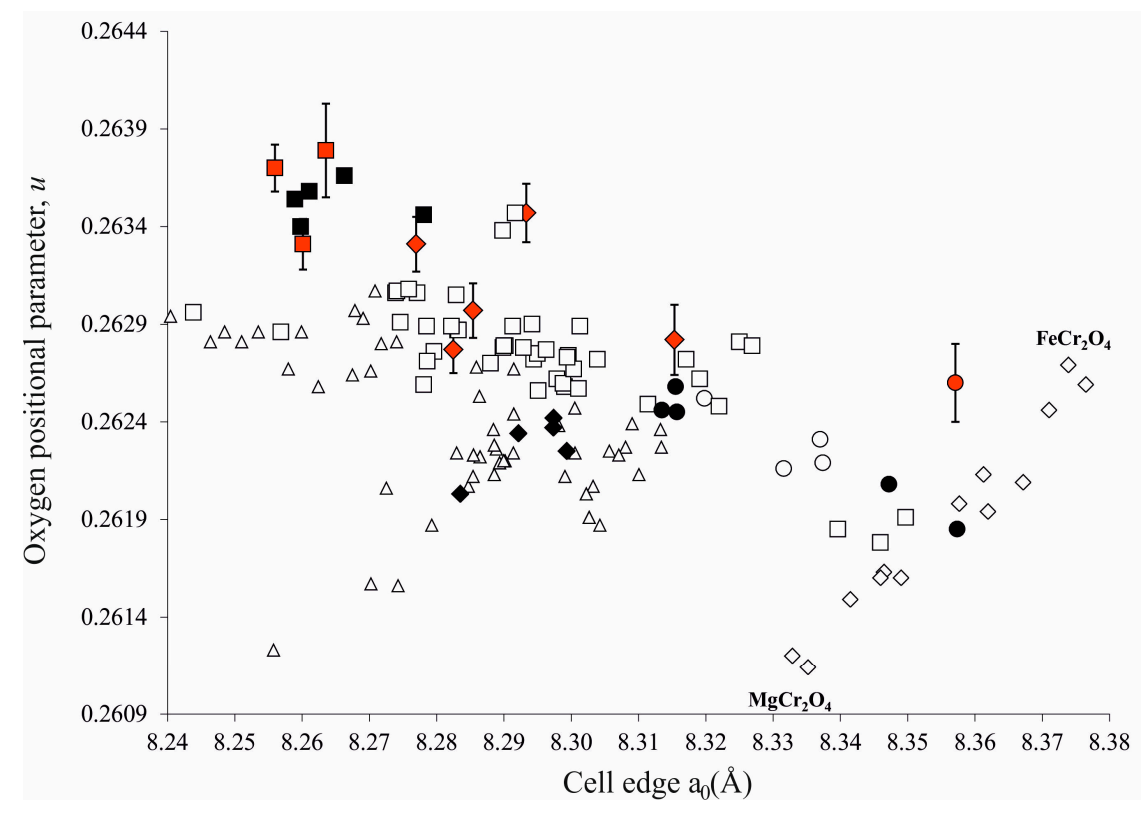

Figure 3. Oxygen positional parameter, $u$, vs cell edge, $\mathrm{a}_{0}$. Red squares, diamonds and circle represent Amsaga Cr-spinels in amphibole, chlorite and talc-serpentine matrix, respectively; open circles represent komatiites from Nuggihalli Cr-spinels [21]; open squares represent Bushveld, Rum and Stillwater Cr-spinels [22-24]; open triangles represent ophiolites [14,16-18]; open diamonds represent $\mathrm{MgCr}_{2} \mathrm{O}_{4}-\mathrm{FeCr}_{2} \mathrm{O}_{4}$ synthetic spinels [52]; full squares, diamonds and circles represent $\mathrm{Cr}$-spinels from Archean complexes of Fiskenaesset, Zimbabwe and Ujaragssuit [31].

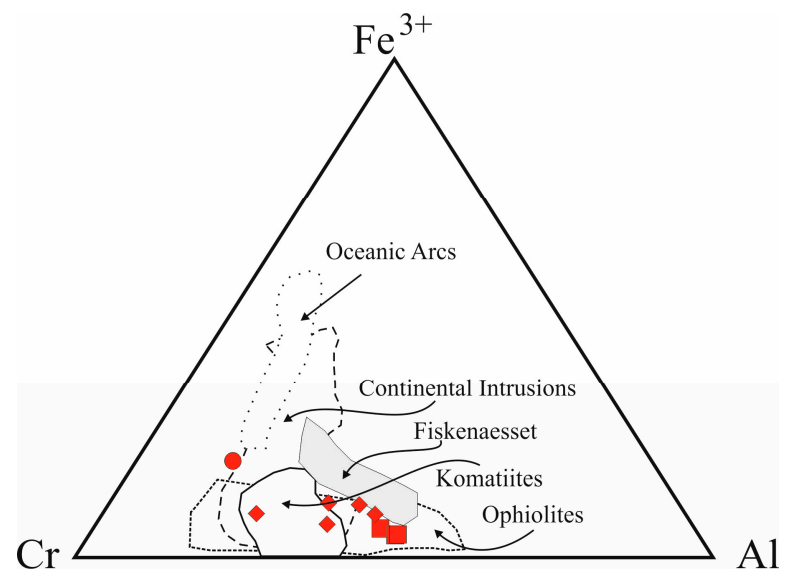

Figure 4. The studied spinels in the $\mathrm{Cr}-\mathrm{Fe}^{3+}-\mathrm{Al}$ triangular plot. Symbols are as in Figure 2; fields of oceanic arcs, continental intrusions, komatiites and ophiolites are based on Barnes and Roeder (2001) [4], Fiskenæsset field is based on Rollinson et al. (2010) [40]. 
Representative Mössbauer spectra of the studied chromite samples are shown in Figure 6, and the results from the spectral fitting, including hyperfine parameters, absorption areas and oxidation ratios, after correction for different $\mathrm{Fe}^{2+}$ and $\mathrm{Fe}^{3+}$ recoil-free fractions, are listed in Table 3. The obtained $\mathrm{Fe}^{3+} / \mathrm{Fe}_{\text {tot }}$ oxidation ratios show pronounced variation from a minimum value of $12 \%$ to a maximum value of $27 \%$, which is markedly coupled to sample host lithology. More precisely, the CHL-CHR samples are relatively oxidized with ratios in the range $21-27 \%$, while those in the AMP-CHR matrix display more reduced ratios in the range of $12-17 \%$. The single sample from the TS matrix shows an oxidation ratio of $22 \%$, which is within the range of the CHL-CHR samples. The oxidation ratios obtained from Mössbauer spectroscopy are normally quite similar to those calculated based on the chemical analyses and charge considerations (Figure 7), which confirms that the samples are stoichiometric. An exception is sample MA422 for which the EMPA data show a considerably higher $\mathrm{Fe}^{3+} / \mathrm{Fe}_{\text {tot }}$ ratio compared to the MS data.

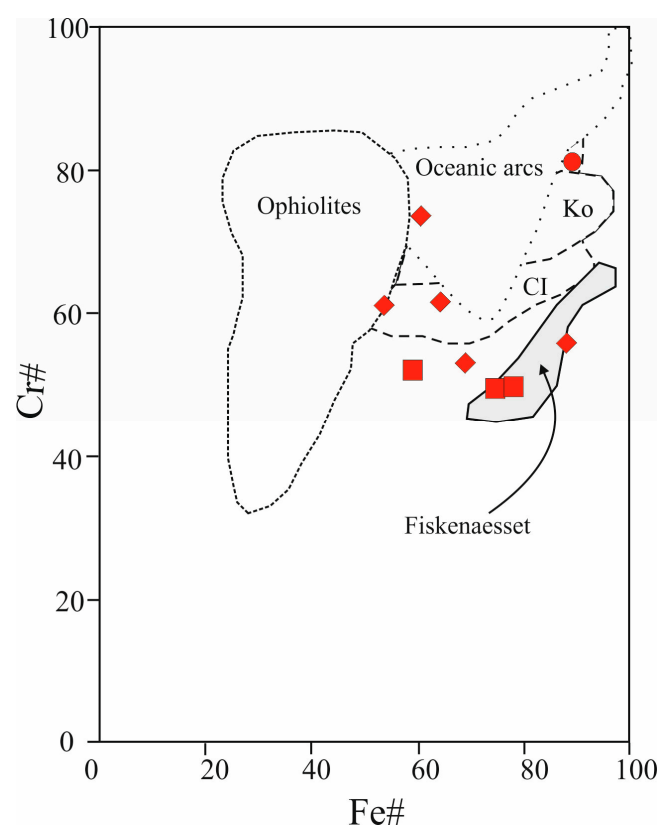

Figure 5. Cr\# vs. Fe\# diagram. Symbols are as in Figure 2. Fields of oceanic arcs, continental intrusions (CI), komatiites (Ko) and ophiolites are based on Barnes and Roeder (2001) [4], Fiskenæsset field is based on Rollinson et al. (2010) [40].

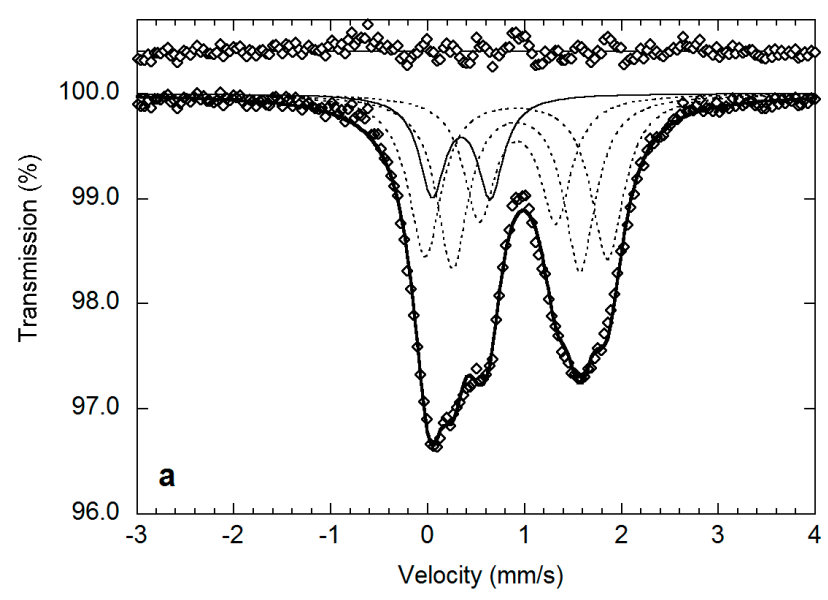

Figure 6. Cont. 

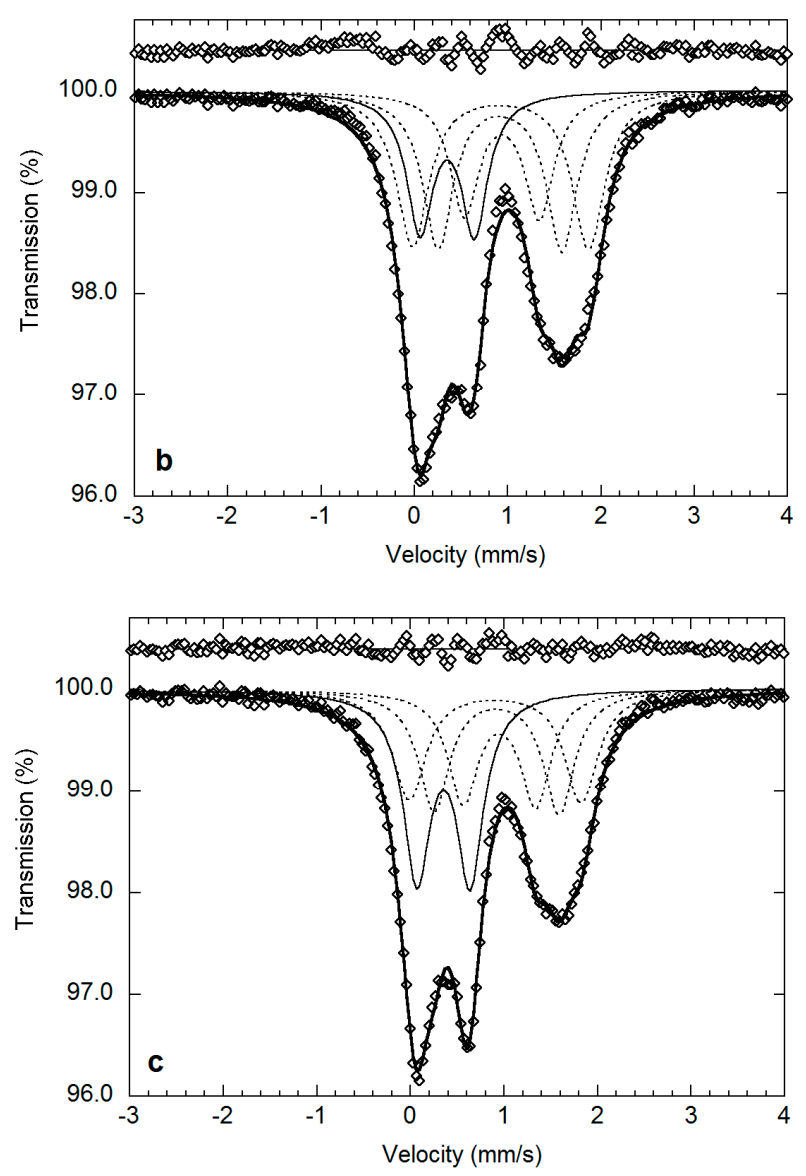

Figure 6. Mössbauer spectra of spinel samples obtained at room temperature showing increasing amounts of $\mathrm{Fe}^{3+}$. (a) Sample MA425; (b) Sample MA273; (c) Sample MA44. Stippled line indicates $\mathrm{Fe}^{3+}$, thin solid lines indicate $\mathrm{Fe}^{2+}$, and thick solid line denotes summed fitted spectrum.

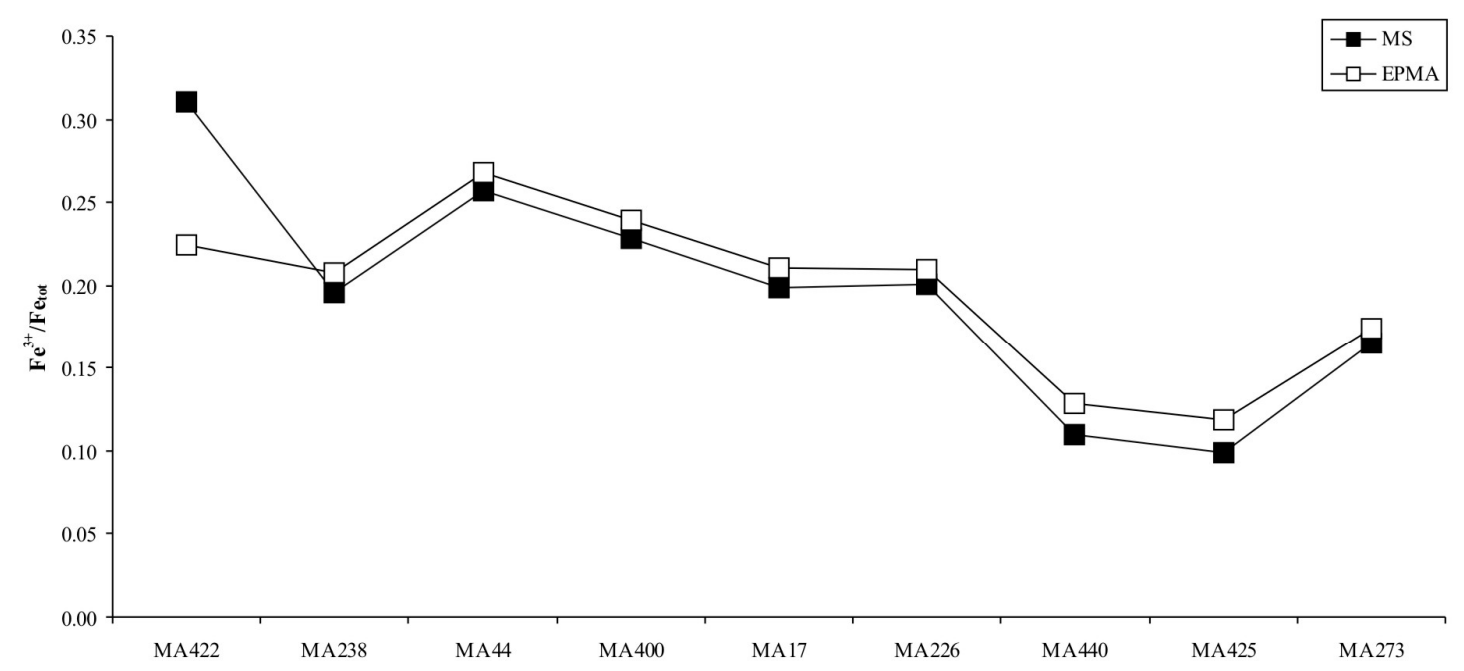

Figure 7. $\mathrm{Fe}^{3+} / \mathrm{Fe}_{\text {tot }}$ comparison according to Mössbauer (MS) and Electron Microprobe Analysis (EMPA). 


\section{Discussion}

\subsection{Crystal Chemical Considerations}

From a structural point of view, the Cr-bearing spinels from the Guelb El Azib complex are similar to those from continental intrusions, like Bushveld and Stillwater [22,24] (Figure 3). However, at least some of them show higher oxygen parameter values, typical of a more ordered distribution with trivalent cations in the $\mathrm{M}$ site and divalent cations in the $\mathrm{T}$ site, which indicates slow cooling. The observed oxygen parameters are rather different from samples from ophiolites [14,16-18]. According to the petrological observations and in comparison with experimental data by [39], the formation of the complex can be explained by fractionation of a slightly hydrous high-alumina basaltic melt at low pressure. The early fractionation of olivine and the absence of massive clinopyroxene fractionation before plagioclase saturation led to crystallization of highly calcic plagioclase with $\mathrm{Fe}$ - and Al-rich, but Cr-poor, chromite, from a hydrous tholeiitic parental magma, similar to worldwide Archean tholeiites. In the $\mathrm{Cr}-\mathrm{Fe}^{3+}$-Al plot (Figure 4), the AMP-CHR spinels fall in the field of ophiolites, while the CHL-CHR samples fall in the area where overlapping occurs between the ophiolite, komatiite and continental intrusion fields. In the Cr\# vs. Fe\# diagram (Figure 5), some of the here-studied spinels fall in the Fiskenæsset field, others in the overlapping fields of oceanic arcs, komatiites and continental intrusions. Rollinson et al. (2010) [40] supposed an igneous origin for the amphibole present in the anorthositic chromitites of Fiskenæsset that seem to be analogous to the chromitites we examined herein. The presence of associated talc-serpentine and chlorite-bearing chromitite rocks in Amsaga make us confident in hypothesizing one or more metamorphic events affecting these rocks, so that the presence of amphiboles could be related to the metamorphism [39]. According to these authors, it is not possible to establish which were the primary igneous structures, textures, modal and mineralogical compositions because of the metamorphism that pervaded the Guelb el Azib complex, which means that the "primary" composition of the here-studied spinels is unclear. Amphibolite-hosted spinels are generally characterized by high $\mathrm{Al}$ and $\mathrm{Mg}$ contents, according to [53], and their paragenesis seems to be the result of pyroxene-consuming retrograde metamorphism that produces amphibole as a secondary phase. The composition of these spinels is typical of high temperature (granulite to amphibolites facies conditions) meta-troctolites [39]. Their composition suggests that high-grade metamorphism has led to enrichment in the spinel end-member with leaching of $\mathrm{Cr}$ [39].

During the second phase of the metamorphism, they crossed the transition from lower amphibolites facies to upper greenschist facies. Within the CHL-CHR group, there is a decrease in $\mathrm{Al}$ and an increase in $\mathrm{Mg}$, in spinels, possibly due to the breakdown of the aluminous Cr-bearing spinel and other coexisting Mg-rich phases. In this step, there is a small increase in $\mathrm{Mg}$ in spinel, with the remaining $\mathrm{Mg}$, and almost all $\mathrm{Al}$, entering chlorite. The third step is characterized by a shift from high grade greenschist to low grade greenschist [39]. According to the literature concerning the metamorphic alteration of Cr-spinels [53-59] during greenschist facies metamorphism, Mg- and Si-rich fluids (derived from low temperature serpentinization of olivine and pyroxenes) react with chromite to form chlorite; as a consequence, chromite was altered to form a FeO- and $\mathrm{Cr}_{2} \mathrm{O}_{3}$-rich, and $\mathrm{Al}_{2} \mathrm{O}_{3}$-poor chromite. This process caused a shift in both cell edge and $u$ to their actual positions in Figure 2, close to the $\mathrm{FeCr}_{2} \mathrm{O}_{4}$ end-member [52]. At the same time, $\mathrm{Mg}$, diffusing out from chromite and olivine present in the former olivine-chromitite rocks, entered into talc and serpentine minerals. Then, during lower temperature amphibolite facies metamorphism, there is the replacement of the primary and previously altered chromite by $\mathrm{Fe}_{2} \mathrm{O}_{3}$-rich chromite (ferritchromite).

\subsection{Thermometric Considerations and Oxidation Evaluation}

According to phase diagram calculations and amphibole-plagioclase thermometry, the Guelb el Azib complex underwent granulite facies metamorphism, followed by retrogression in the amphibolite facies $\left(650-800^{\circ} \mathrm{C}\right)$, where green hornblende, resembling those from amphibole-chromitite, formed [39]. Similar temperatures were determined with the thermometer by [60] on the amphibole-chromitites. 
Our samples show a continuous evolution from an Al-chromite type to an almost pure chromite type, with crystallographic features suggesting an initial weak recrystallization, with subsequent low-temperature oxidation. Gervilla et al. (2012) [61] showed that between 550 and $700{ }^{\circ} \mathrm{C}$ (depending on pressure), the infiltration of water into chromitites might promote the reaction of primary chromite with matricial olivine to produce chlorite in equilibrium with "secondary" chromite residually enriched in $\mathrm{Cr}$ and $\mathrm{Fe}^{2+}$ (ferrous chromite). According to these authors, this reaction produces $\sim 43 \%$ loss of the mass of chromite that is not compensated by modification of the initial size of the chromite grain, but by the development of a spongy or porous texture in the ferrous chromite. They also observed that some pores remain empty. Those pores are unlikely to remain open unless this occurs at the surface-so the open pores may originally have been fluid-filled. However, most of them are now filled by chlorite, produced as a consequence of the abovementioned reaction. Lenaz et al. (2014) [17] showed that in Oman ophiolite, the temperature of oxidation ranges between 675 and $861{ }^{\circ} \mathrm{C}$ (olivine-chromite thermometry) [62]. According to several authors [53,54,58,63], the temperature at which ferritchromite forms is between 500 and $600{ }^{\circ} \mathrm{C}$. Given this, it is possible to assume that non-stoichiometric spinels with abundant cation vacancies in the structure are the result of an oxidation event that took place at a temperature between the one of ferritchromite formation and the one calculated for the not oxidized spinels, i.e., more or less in the range 600 and $700{ }^{\circ} \mathrm{C}$. The high Cr\# promotes the formation of structural vacancies during oxidation, possibly because in such samples, where the chromite component is abundant, it is easier to oxidize $\mathrm{Fe}^{2+}$ and create vacancies following the reaction $3 \mathrm{Fe}^{2+}+\mathrm{O}_{2} \rightarrow 2 \mathrm{Fe}^{3+}+\square$, where $\square$ is a structural vacancy [29]. Even if metamorphic processes are evident, the $f_{\mathrm{O} 2}$ in Amsaga was not sufficient to create non-stoichiometric spinels, possibly due to the low chromite component (i.e., low $\mathrm{Fe}^{2+}$ and $\mathrm{Cr}$ content) of the present spinels. However, a continuous increase in the $\mathrm{Fe}^{3+} / \mathrm{Fe}_{\text {tot }}$ ratio, from the AMP-CHR to the TS-CHR spinels, can be discerned.

Recently, Lenaz et al. [64] showed that powder Mössbauer spectroscopy determination of $\mathrm{Fe}^{3+} / \mathrm{Fe}_{\text {tot }}$ ratios in some cases can differ considerably from that calculated via EMPA, due to the fact that grains with different oxidation degrees may be present in the powders, demonstrating the advantage of point-source Mössbauer measurements. Nevertheless, in the present case, the comparison between $\mathrm{Fe}^{3+} / \mathrm{Fe}_{\text {tot}}$, measured with EMPA and Mössbauer, generally shows only a small difference (Table 3; Figure 7), apart from the TS-CHR (MA422) sample. Consequently, all the other samples can be considered homogeneous and stoichiometric. The reason for the larger difference observed for the MA422 sample is likely related to differences in $\mathrm{Fe}^{3+} / \mathrm{Fe}_{\text {tot }}$ between individual crystals showing a large spread of spinel compositions, due to hydrothermal alteration and the presence of magnetite, as evidenced by MS analysis and petrographic observations [39], and the fact that the Mössbauer data is based on analysis of a number of crystals, as opposed to the single-crystal XRD data.

Cr-bearing spinels have been considered important petrogenetic indicators by many authors [65-71], due to their chemical variability in parental melt composition and/or crystallization conditions in igneous rocks, and as paleogeographic indicators in geodynamic reconstructions, because of their resistance to mechanical stress, weathering and diagenesis in sedimentary environments. Commonly-used diagrams for these purposes are the $\mathrm{Cr} \#$ vs. $\mathrm{Mg} \#$ and the $\mathrm{TiO}_{2} \mathrm{vs} \mathrm{Al}_{2} \mathrm{O}_{3}[3,5]$ as well as the $\mathrm{Cr}-\mathrm{Fe}^{3+}-\mathrm{Al}$ ternary plot. However, as can be seen in Figures 4 and 5, these diagrams show considerable overlap between several occurrences. Interestingly, the oxygen positional parameter of the spinels seems to be a distinctive feature. In fact, our preliminary data evidence how spinels from amphibolites show higher values than those from ophiolite hosted $\mathrm{Cr}$-spinels, being unique in such cases. To our knowledge, only two structural studies have been performed on detrital spinels to identify their possible sources [72,73]. The preliminary data obtained in this study seem promising because they could be a valuable help in discriminating the source when the exact provenance of detrital spinels is ambiguous, as also evidenced by [25]. 


\section{Conclusions}

In the past few years, most studies on Cr-bearing spinels have dealt with possible non-stoichiometry from different spinel occurrences. In the present study, the general agreement between electron microprobe and Mössbauer data indicates that the analyzed spinels were stoichiometric. Moreover, the structural data revealed that the oxygen positional parameter of amphibole-bearing samples was the highest observed among Cr-bearing spinels with similar Cr\# and Mg\#. Consequently, it is suggested that a structural study of detrital Cr-spinels could be important in discriminating an amphibole-chromitite source from an ophiolite source.

Acknowledgments: The Italian C.N.R. financed the installation and maintenance of the microprobe laboratory in Padova. R. Carampin and L. Tauro are kindly acknowledged for technical support. Thanks to G.D. Bromiley at Edinburgh University for a revision of an early version of the manuscript. This work was supported with MURST and Trieste University grants to D.L. (FRA 2009 and PRIN 2010-11). J.B. has been financed by a FRS-FNRS grant and thanks the OMRG for technical support during the fantastic fieldtrip in the Amsaga. H.S. acknowledge support from the Swedish Research Council. Three reviewers are kindly acknowledged for their comments.

Author Contributions: D.L., N.R. and J.B. conceived and designed the project; D.L. and N.R. performed and discussed the XRD analyses; H.S. performed and discussed the Mössbauer analyses; D.L. wrote the paper.

Conflicts of Interest: The authors declare no conflict of interest.

\section{References}

1. Irvine, T.N. Chromian spinel as a petrogenetic indicator. Part 2. Petrologic applications. Can. J. Earth Sci. 1967, 4, 71-103. [CrossRef]

2. Dick, H.J.B.; Bullen, J.H. Chromian spinel as petrogenetic indicator in abyssal and alpine-type peridotites and spatially associated lavas. Contrib. Mineral. Petrol. 1984, 86, 54-76. [CrossRef]

3. Lenaz, D.; Kamenetsky, V.S.; Crawford, A.J.; Princivalle, F. Melt inclusions in detrital spinels from the SE Alps (Italy-Slovenia): A new approach to provenance studies of sedimentary basins. Contrib. Mineral. Petrol. 2000, 139, 748-758. [CrossRef]

4. Barnes, S.J.; Roeder, P.L. The range of spinel compositions in terrestrial mafic and ultramafic rocks. J. Petrol. 2001, 42, 2279-2302. [CrossRef]

5. Kamenetsky, V.S.; Crawford, A.J.; Meffre, S. Factors controlling chemistry of magmatic spinel: An empirical study of associated olivine, Cr-spinel and melt inclusions from primitive rocks. J. Petrol. 2001, 42, 655-671. [CrossRef]

6. Sack, R.O.; Ghiorso, M.S. Chromian spinels as petrogenetic indicators: Thermodynamics and petrological applications. Am. Mineral. 1991, 76, 827-847.

7. Roeder, P.L. Chromite: From the Fiery rain of chondrules to the Kilauea Iki lava lake. Can. Mineral. 1994, 32, 729-746.

8. Della Giusta, A.; Princivalle, F.; Carbonin, S. Crystal chemistry of a suite of natural Cr-bearing spinels with $0.15<\mathrm{Cr}<1.07$. N. Jahrb. Min. Abh. 1986, 155, 319-330.

9. Princivalle, F.; Della Giusta, A.; Carbonin, S. Comparative crystal chemistry of spinels from some suits of ultramafic rocks. Mineral. Petrol. 1989, 40, 117-126. [CrossRef]

10. Princivalle, F.; De Min, A.; Lenaz, D.; Scarbolo, M.; Zanetti, A. Ultramafic xenoliths from Damaping (Hannuoba region, NE-China): Petrogenetic implications from crystal chemistry of pyroxenes, olivine and Cr-spinel and trace element content of clinopyroxene. Lithos 2014, 188, 3-14. [CrossRef]

11. Nédli, Z.; Princivalle, F.; Lenaz, D.; Tóth, T.M. Crystal chemistry of clinopyroxene and spinel from mantle xenoliths hosted in late Mesozoic lamprophyres (Villány Mts, S Hungary). N. Jahrb. Min. Abh. 2008, 185, 1-10. [CrossRef]

12. Lenaz, D.; Youbi, N.; De Min, A.; Boumehdi, M.A.; Ben Abbou, M. Low intra-crystalline closure temperatures of Cr-bearing spinels from the mantle xenoliths of the Middle Atlas Neogene-Quaternary Volcanic Field (Morocco): A mineralogical evidence of a cooler mantle beneath the West African Craton. Am. Mineral. 2014, 99, 267-275. [CrossRef] 
13. Perinelli, C.; Bosi, F.; Andreozzi, G.B.; Conte, A.M.; Armienti, P. Geothermometric study of Cr-spinels of peridotite mantle xenoliths from Northern Victoria Land (Antarctica). Am. Mineral. 2014, 99, 839-846. [CrossRef]

14. Bosi, F.; Andreozzi, G.B.; Ferrini, V.; Lucchesi, S. Behavior of cation vacancy in kenotetrahedral Cr-spinels from Albanian eastern belt ophiolites. Am. Mineral. 2004, 89, 1367-1373. [CrossRef]

15. Quintiliani, M.; Andreozzi, G.B.; Graziani, G. $\mathrm{Fe}^{2+}$ and $\mathrm{Fe}^{3+}$ quantification of different approaches and $\mathrm{fO}_{2}$ estimation for Albanian Cr-spinels. Am. Mineral. 2006, 91, 907-916. [CrossRef]

16. Derbyshire, E.J.; O’Driscoll, B.; Lenaz, D.; Gertisser, R.; Kronz, A. Compositional heterogeneity in chromitite seams from the Shetland Ophiolite Complex (Scotland). Lithos 2013, 162-163, 279-300. [CrossRef]

17. Lenaz, D.; Adetunji, J.; Rollinson, H. Determination of $\mathrm{Fe}^{3+} / \Sigma \mathrm{Fe}$ ratios in chrome spinels using a combined Mössbauer and single-crystal X-ray approach: Application to chromitites from the mantle section of the Oman ophiolite. Contrib. Mineral. Petrol. 2014, 167, 958. [CrossRef]

18. Lenaz, D.; Andreozzi, G.B.; Bidyananda, M.; Princivalle, F. Oxidation degree of chromite from Indian ophiolites: A crystal chemical and ${ }^{57} \mathrm{Fe}$ Mössbauer study. Per. Mineral. 2014, 83, 241-255. [CrossRef]

19. Basso, R.; Comin-Chiaramonti, P.; Della Giusta, A.; Flora, O. Crystal chemistry of four Mg-Fe-Al-Cr spinels from the Balmuccia peridotite (Western Italian Alps). N. Jahrb. Min. Abh. 1984, 150, 1-10.

20. Lenaz, D.; De Min, A.; Garuti, G.; Zaccarini, F.; Princivalle, F. Crystal chemistry of Cr-spinels from the lherzolite mantle peridotite of Ronda (Spain). Am. Mineral. 2010, 95, 1323-1328. [CrossRef]

21. Lenaz, D.; Andreozzi, G.B.; Mitra, S.; Bidyananda, M.; Princivalle, F. Crystal chemical and ${ }^{57}$ Fe Mössbauer study of chromite from the Nuggihalli schist belt (India). Mineral. Petrol. 2004, 80, 45-57. [CrossRef]

22. Lenaz, D.; Braidotti, R.; Princivalle, F.; Garuti, G.; Zaccarini, F. Crystal chemistry and structural refinement of chromites from different chromitite layers and xenoliths of the Bushveld Complex. Eur. J. Mineral. 2007, 19, 599-609. [CrossRef]

23. Lenaz, D.; O'Driscoll, B.; Princivalle, F. Petrogenesis of the anorthosite-Chromitite association: Crystal-chemical and petrological insights from the Rum Layered Intrusion, NW Scotland. Contrib. Mineral. Petrol. 2011, 162, 1201-1213. [CrossRef]

24. Lenaz, D.; Garuti, G.; Zaccarini, F.; Cooper, R.W.; Princivalle, F. The Stillwater Complex: The response of chromite crystal chemistry to magma injection. Geol. Acta 2012, 10, 33-41. [CrossRef]

25. Lenaz, D.; Logvinova, A.M.; Princivalle, F.; Sobolev, N.V. Structural parameters of chromite included in diamond and kimberlites from Siberia: A new tool for discriminating ultramafic source. Am. Mineral. 2009, 94, 1067-1070. [CrossRef]

26. Lenaz, D.; Princivalle, F.; Schmitz, B. First crystal-structure determination of chromites from an acapulcoite and ordinary chondrites. Min. Mag. 2015, 79, 755-765. [CrossRef]

27. Lenaz, D.; Schmitz, B. Crystal structure refinement of chromites from two achondrites, their T-f $\left(\mathrm{O}_{2}\right)$ conditions and implications. Meteor. Planet. Sci. 2017, 52, 1763-1775. [CrossRef]

28. Ashwal, L.D. Anorthosites; Springer: Berlin, Germany, 1993; p. 422.

29. Carbonin, S.; Menegazzo, G.; Lenaz, D.; Princivalle, F. Crystal chemistry of two detrital Cr-spinels with unusually low values of oxygen positional parameter: Oxidation mechanism and possible origin. N. Jahrb. Min. Mh. 1999, 8, 359-371.

30. Rollinson, H.; Adetunji, J.; Yousif, A.A.; Gismelseed, A.M. New Mössbauer measurements of $\mathrm{Fe}^{3+} / \Sigma \mathrm{Fe}^{2}$ in chromites from the mantle section of the Oman ophiolites: Evidence for the oxidation of the sub-oceanic mantle. Min. Mag. 2012, 76, 579-596. [CrossRef]

31. Rollinson, H.; Adetunji, J.; Lenaz, D.; Szilas, K. Archaean chromitites show constant $\mathrm{Fe}^{3+} / \Sigma \mathrm{Fe}$ in Earth's asthenospheric mantle since $3.8 \mathrm{Ga}$. Lithos 2017, 282-283, 316-325. [CrossRef]

32. Adetunji, J.; Everitt, S.; Rollinson, H. New Mössbauer measurements of $\mathrm{Fe}^{3+} / \Sigma \mathrm{Fe}$ ratios in chromites from the early Proterozoic Bushveld Compex, South Africa. Precambrian Res. 2013, 228, 194-205. [CrossRef]

33. Rollinson, H.; Adetunji, J. Mantle podiform chromitites do not form beneath mid-ocean ridges: A case study from the Moho transition zone of the Oman ophiolite. Lithos 2013, 177, 314-327. [CrossRef]

34. Rollinson, H.; Adetunji, J. The geochemistry and oxidation state of podifrom chromitites from the mantle section of the Oman ophiolite: A review. Gondwana Res. 2015, 27, 543-554. [CrossRef]

35. Potrel, A. Geochemistry of the Amsaga area orthogneisses (Archean Reguibat Rise, Mauritania). Rev. Bras. Geosci. 1996, 27, 211-218. 
36. Auvray, B.; Peucat, J.J.; Potrel, A.; Burg, J.P.; Caruba, C.; Lo, K. Données géochronologiques nouvelles sur 1'Archéen de 1'Amsaga (Dorsale Réguibat, Mauritanie). Comptes Rend. Acad. Sci. 1992, 315, 63-70.

37. Potrel, A.; Peucat, J.J.; Fanning, C.M. Archean crustal evolution of the west African Craton: Example of the Amsaga area (Reguibat rise). U-Pb and $\mathrm{Sm}-\mathrm{Nd}$ evidence for crustal growth and recycling. Precambrian Res. 1998, 90, 107-117. [CrossRef]

38. Key, R.M.; Loughlin, S.C.; Gillespie, M.; Del Rio, M.; Horstwood, M.S.A.; Crowley, Q.G.; Darbyshire, D.P.F.; Pitfield, P.E.J.; Henney, P.J. Two Mesoarchaean terranes in the Reguibat shield of NW Mauritania. Geol. Soc. Lond. Spec. Pub. 2008, 297, 33-52. [CrossRef]

39. Berger, J.; Diot, H.; Lo, K.; Ohnenstetter, D.; Féménias, O.; Pivin, M.; Demaiffe, D.; Bernard, A.; Charlier, B. Petrogenesis of Archean PGM-bearing chromitites and associated ultramafic-mafic-anorthositic rocks from the Guelb el Azib complex (West African craton, Mauritania). Precambrian Res. 2013, 224, 612-628. [CrossRef]

40. Rollinson, H.R.; Reid, C.; Windley, B. Chromitites from the Fiskenæsset anorthositic complex, West Greenland: Clues to late Archaean mantle processes. In The Evolving Continents: Understanding Processes of Continental Growth; Kusky, T.M., Zhai, M.-G., Xiao, W., Eds.; Geological Society, Special Publication: London, UK, 2010; Volume 338, pp. 197-212.

41. Dutta, U.; Bhui, U.K.; Sengupta, P.; Sanyal, S.; Mukhopadhyay, D. Magmatic and metamorphic imprints in 2.9 Ga chromitites from the Sittampundi layered complex, Tamil Nadu, India. Ore Geol. Rev. 2011, 40, 90-107. [CrossRef]

42. Ghosh, B.; Konar, R. Chromites from meta-anorthosites, Sittampundi layered igneous complex, Tamil Nadu, Southern India. J. Asian Earth Sci. 2011, 42, 1394-1402. [CrossRef]

43. Della Giusta, A.; Carbonin, S.; Ottonello, G. Temperature-dependant disorder in a natural Mg-Al-Fe ${ }^{2+}-\mathrm{Fe}^{3+}$-Spinel. Min. Mag. 1996, 60, 603-616. [CrossRef]

44. Sheldrick, G.M. A short history of SHELX. Acta Crystallogr. 2008, 64, 112-122. [CrossRef] [PubMed]

45. Prince, E. Volume C: Mathematical, Physical and Chemical Tables. In International Tables for X-ray Crystallography, 3rd ed.; Springer: Dordrecht, The Netherlands, 2004.

46. Tokonami, M. Atomic scattering factor for $\mathrm{O}^{-2}$. Acta Crystallogr. 1965, 19, 486. [CrossRef]

47. Carbonin, S.; Russo, U.; Della Giusta, A. Cation distribution in some natural spinels from X-ray diffraction and Mössbauer spectroscopy. Min. Mag. 1996, 60, 355-368. [CrossRef]

48. Lavina, B.; Salviulo, G.; Della Giusta, A. Cation distribution and structure modelling of spinel solid solutions. Phys. Chem. Min. 2002, 29, 10-18. [CrossRef]

49. Jernberg, P.; Sundqvist, T. A Versatile Mössbauer Analysis Program; Institute of Physics (UUIP-1090), Uppsala University: Uppsala, Sweden, 1983.

50. De Grave, E.; Van Alboom, A. Evaluation of ferrous and ferric Mössbauer fractions. Phys. Chem. Min. 1991, 18, 337-342. [CrossRef]

51. Eeckhout, S.G.; De Grave, E. Evaluation of ferrous and ferric Mossbauer fractions. Part II. Phys. Chem. Min. 2003, 30, 142-146. [CrossRef]

52. Lenaz, D.; Skogby, H.; Princivalle, F.; Hålenius, U. Structural changes and valence states in the $\mathrm{MgCr}_{2} \mathrm{O}_{4}-\mathrm{FeCr}_{2} \mathrm{O}_{4}$ solid solution series. Phys. Chem. Min. 2004, 31, 633-642. [CrossRef]

53. Kimball, K.M. Effects of hydrothermal alteration on the compositions of chromian spinels. Contrib. Mineral. Petrol. 1990, 105, 337-346. [CrossRef]

54. Evans, B.W.; Frost, B.R. Chrome-spinel in progressive metamorphism-A preliminary analysis. Geochim. Cosmochim. Acta 1975, 39, 959-972. [CrossRef]

55. Burkhard, D.J.M. Accessory chromium spinels: Their coexistence and alteration in serpentinites. Geochim. Cosmochim. Acta 1993, 57, 1297-1306. [CrossRef]

56. Barnes, S.J. Chromite in Komatiites, 2. Modifications during greenschist to mid-amphibolite facies metamorphism. J. Petrol. 2000, 41, 387-409. [CrossRef]

57. Farahat, E.S. Chrome-spinels in serpentinites and talc-carbonates of the El Ideid-El Sodmein District, central Eastern Desert, Egypt: Their metamorphism and petrogenetic implications. Chem. Erde 2005, 68, 193-205. [CrossRef]

58. Mellini, M.; Rumori, C.; Viti, C. Hydrotermally reset magmatic spinels in retrograde serpentinites: Formation of "ferritchromit" rims and Chlorite aureoles. Contrib. Mineral. Petrol. 2005, 149, 266-275. [CrossRef]

59. Merlini, A.; Grieco, G.; Diella, V. Ferritchromite and chromian-chlorite formation in melange-hosted Kalkan chromitite (Southern Uurals, Russia). Am. Mineral. 2009, 94, 1459-1467. [CrossRef] 
60. Princivalle, F.; Della Giusta, A.; De Min, A.; Piccirillo, E.M. Crystal chemistry and significance of cation ordering in Mg-Al rich spinels from high-grade hornfels (Predazzo-Monzoni, NE Italy). Min. Mag. 1999, 63, 257-262. [CrossRef]

61. Gervilla, F.; Padrón-Navarta, J.A.; Kerestedjian, T.; Sergeeva, I.; González-Jiménez, J.M.; Fanlo, I. Formation of ferrian chromite in podiform chromitites from the Golyamo Kamenyane serpentinite, Eastern Rhodopes, SE Bulgaria: A two-stage process. Contrib. Mineral. Petrol. 2012, 164, 643-657. [CrossRef]

62. Ballhaus, C.; Berry, R.F.; Green, D.H. High pressure experimental calibration of the olivine-orthopyroxene-spinel oxygen geobarometer: Implications for the oxidation state of the upper mantle. Contrib. Mineral. Petrol. 1991, 107, 27-40. [CrossRef]

63. González-Jiménez, J.M.; Kerestedjian, T.; Proenza, J.A.; Gervilla, F. Metamorphism on chromite ores from the Dobromirtsi ultramafic massif, rhodope mountains (SE Bulgaria). Geol. Acta 2009, 7, 413-429.

64. Lenaz, D.; Skogby, H.; Logvinova, A.M.; Sobolev, N.V.; Princivalle, F. A micro-Mössbauer study of chromites included in diamond and other mantle-related rocks. Phys. Chem. Min. 2013, 40, 671-679. [CrossRef]

65. Lenaz, D.; Kamenetsky, V.; Princivalle, F. Cr-spinel supply in the Brkini, Istrian and Krk Island flysch basins (Slovenia, Italy and Croatia). Geol. Mag. 2003, 140, 335-372. [CrossRef]

66. Lenaz, D.; Mazzoli, C.; Spišiak, J.; Princivalle, F.; Maritan, L. Detrital Cr-spinel in the Šambron-Kamenica Zone (Slovakia): Evidence for an ocean-spreading zone in the Northern Vardar suture? Int. J. Earth Sci. 2009, 98, 345-355. [CrossRef]

67. Abre, P.; Cingolani, C.; Zimmermann, U.; Cairncross, B. Detrital chromian spinels from Upper Ordovician depostis in the Precordillera terrane, Argentina: A mafic crust input. J. S. Am. Earth Sci. 2009, 28, 407-418. [CrossRef]

68. Lužar-Oberiter, B.; Mikes, T.; von Eynatten, H.; Babić, L. Ophiolitic detritus in Cretaceous clastic formations of the Dinarides (NW Croatia): Evidence from Cr-spinel chemistry. Int. J. Earth Sci. 2009, 98, 1097-1108. [CrossRef]

69. Filippov, A.N. Compositions and provenances of Mesozoic sandstones in Sikhote Alin. Lithol. Min. Res. 2012, 47, 70-88. [CrossRef]

70. Barkov, A.Y.; Nixon, G.T.; Levson, V.M.; Martin, R.F.; Fleet, M.E. Chromian spinel from PGE-bearing placer deposits, British Columbia, Canada: Mineralogical associations and provenance. Can. Mineral. 2013, 51, 501-536. [CrossRef]

71. Ghosh, B.; Morishita, T.; Bhatta, K. Detrital chromian spinels from beach placers of Andaman Islands, India: A perspective view of petrological characteristics and variations of the Andaman ophiolite. Island Arc 2012, 21, 188-201. [CrossRef]

72. Lenaz, D.; Princivalle, F. Crystal-chemistry of detrital chromites in sandstones from Trieste (NE Italy). N. Jahrb. Min. Mh. 1996, 9, 429-434.

73. Lenaz, D.; Princivalle, F. The crystal chemistry of detrital chromian spinel from the Southeastern Alps and Outer Dinarides: The discrimination of supplies from areas of similar tectonic setting? Can. Mineral. 2005, 43, 1305-1314. [CrossRef]

(C) 2018 by the authors. Licensee MDPI, Basel, Switzerland. This article is an open access article distributed under the terms and conditions of the Creative Commons Attribution (CC BY) license (http://creativecommons.org/licenses/by/4.0/). 